DOI: 10.34185/1991-7848.itmm.2020.01.004

\title{
КЛАССИФИКАЦИЯ ФАКТОРОВ РИСКА ПРИ РАБОТЕ КОНВЕЙЕРНОГО ТРАНСПОРТА НА ГОРНЫХ ПРЕДПРИЯТИЯХ
}

Кирия Р. В. д.т.н., с.н.с., Смирнов А. Н. к.т.н., Мищенко Т. Ф. Институт геотехнической механики им. Н. С. Полякова НАН Украины

Аннотация. В работе проведена классификация факторов риска ленточных конвейеров, работающих на открытых горных предприятиях и в угольных шахтах с точки зрения наносимого ущерба: технического, экономического, экологического и социального.

Проведен предварительный анализ риска ленточных конвейеров, включая модификацию опасностей, т.е. выявление опасностей и предварительная оценка характеристик опасностей.

В результате выявлены основные факторы риска ленточных конвейеров и получено дерево отказов ленточных конвейеров, работающих на горных предприятиях.

Анализ риска всех типов ленточных конвейеров (общего назначения, глубокожелобчатых, с прижимной лентой и вертикальных) показал, что наиболее опасным воздействием на окружающую среду являются конвейеры общего назначения и вертикальные. При этом для крутонаклонных конвейеров с глубокожелобчатой лентой, а также вертикальных конвейеров существенным фактором опасности является неустойчивость крупных кусков груза на ленте конвейера.

Ключевые слова: ленточные конвейеры, горные предприятия, факторы риска, анализ риска, надежность и безопасность технических систем.

С увеличением сложности технических систем на первый план выступает проблема обеспечения безопасности жизни и здоровья людей, охрана окружающей среды, а также материальные потери, возникающие при аварийных ситуациях [1,2]. В большой степени аварийность свойственна горной промышленности, в частности, в процессе эксплуатации конвейерного транспорта, который является ключевым звеном при добыче полезных ископаемых.

Решение этих проблем связано, в том числе, с развитием теории надежности и безопасности технических систем и оценкой техногенных рисков [3]. 
International scientific and technical conference Information Technologies in Metallurgy and Machine building - ITMM 2020

В настоящее время применение конвейерного транспорта для глубоких карьеров и угольных шахт потребовало использование новых, более сложных видов ленточных конвейеров, в частности, глубокожелобчатых, трубчатых, с прижимной лентой, а также вертикальных. При этом факторы риска, связанные с применением этих типов конвейеров в условиях горных предприятий, приводят к большим материальным и человеческим потерям, а также к загрязнению окружающей среды.

В работе проведена классификация факторов риска ленточных конвейеров, работающих на открытых горных предприятиях и в угольных шахтах с точки зрения наносимого ущерба: технического, экономического, экологического и социального.

К основным факторам риска ленточных конвейеров, работающих на горных предприятиях, относятся: отказы оборудования, опасность внешних воздействий и ошибки эксплуатации (уровень обслуживания).

Проведен предварительный анализ риска ленточных конвейеров, включая модификацию опасностей, т.е. выявление опасностей и предварительная оценка характеристик опасностей.

В результате выявлены основные факторы риска ленточных конвейеров и получено дерево отказов ленточных конвейеров, работающих на горных предприятиях.

Анализ риска всех типов ленточных конвейеров (общего назначения, глубокожелобчатых, с прижимной лентой и вертикальных) показал, что наиболее опасным воздействием на окружающую среду являются конвейеры общего назначения и вертикальные. При этом для крутонаклонных конвейеров с глубокожелобчатой лентой, а также вертикальных конвейеров существенным фактором опасности является неустойчивость крупных кусков груза на ленте конвейера.

Наименьший риск для окружающей среды оказывают трубчатые ленточные конвейеры. Однако они имеют большие расходы на устранение аварий и техническое обслуживание. Кроме того, их использование существенно ограничивается крупностью кусков насыпного груза. Поэтому в настоящее время в связи с ужесточением требованиям к экологии преимущество за рубежом получили трубчатые ленточные конвейеры, у которых по сравнению с остальными типами конвейеров отсутствует контакт 
груза с атмосферой. Кроме того, они могут транспортировать груз по криволинейным трассам без перегрузочных узлов.

\section{Литература}

1. Хенли Э. Дж. Надежность технических систем и оценка риска / Э. Дж. Хенли, Х. Кумамото. - М.: Машиностроение, 1984. - 528 с.

2. Надежность технических систем и техногенный риск / В. А. Акимов, В. Л. Лапин, В. М. Попов [и др.]. - М.: ЗАО ФИД «Деловой экспресс», 2002. - 368 с.

3. Половко А. М. Основы теории надежности / А. М. Половко, С. В. Гуров. - СПб.: БХВПетербург, 2008. - 704 с.

\section{CLASSIFICATION OF RISK FACTORS AT WORK CONVEYOR TRANSPORT AT MINING}

Kiriia Ruslan, Smirnov Andrii, Mishchenko Tamara

Abstract. The paper provides a classification of risk factors for conveyor belts operating in open-pit mining enterprises and in coal mines in terms of man-made damage: technical, economic, environmental and social.

A preliminary risk analysis of conveyor belts, including hazard modification, i.e. hazard identification and preliminary assessment of hazard characteristics.

As a result, the main risk factors for conveyor belts were identified and a failure tree of conveyor belts operating in mining enterprises was obtained.

A risk analysis of all types of belt conveyors (general purpose, deep grooved, with clamping belt and vertical) showed that the most dangerous environmental impacts are general purpose and vertical conveyors. At the same time, for steeply inclined conveyors with a deep grooved belt, as well as vertical conveyors, an essential hazard factor is the instability of large pieces of load on the conveyor belt.

Keywords: belt conveyors, mining enterprises, risk factors, risk analysis, reliability and safety of technical systems.

\section{References}

1. Khenly, E. Dzh., Kumamoto, Kh. (1984). Nadezhnost tekhnicheskikh system i otsenka riska. Moscow: Mashinostroenie.

2. Akimov, V. A., Lapin, V. L., Popov, V. M. (2002). Nadezhnost tekhnicheskikh system i tekhnogenny risk. Moscow: ZAO FID “Delovoy ekspress”.

3. Polovko, A. M., Gurov, S. V. (2008). Sankt-Petersburg: BXV-Petersburg. 